\title{
WE ARE ALL HERE TO STAY? INDIGENEITY, MIGRATION, AND 'DECOLONIZING' THE TREATY RIGHT TO BE HERE
}

\author{
Amar Bhatia*
}

This article examines issues of transnational migration in the settler-colonial context of Canada. First, I review some of the recent debates about foregrounding Indigeneity and decolonization in anti-racist thought and work, especially in relation to critical and antiracist approaches to migration. The article then moves from this debate to the question of 'our right to be here', the relationship of this right to the treaties, and how migrant rights and treaty relations perspectives might interact in a context that must be informed by Indigenous laws and legal traditions.

Le présent article se penche sur les questions liées à la migration transnationale dans le contexte du colonialisme de peuplement du Canada. Premièrement, j'examine certains des débats récents sur le traitement prioritaire de l'indigénéité et de la décolonisation dans la pensée antiraciste et les travaux de lutte contre le racisme, notamment par rapport aux approches critiques et antiracistes à la migration. L'article aborde ensuite la question de "notre droit d'être ici », la relation entre ce droit et les traités, ainsi que la façon dont les perspectives sur les droits des migrants et les rapports fondés sur des traités pourraient interagir dans un contexte éclairé par des lois et des traditions juridiques indigènes.

"Capitalist production, therefore, develops technology, and the combining together of various processes into a social whole, only by sapping the original sources of all wealth — the soil and the labourer."

Karl Marx, Capital: A Critique of Political Economy [1867], Vol. 1, 326

"Let's face it, we are all here to stay."

Antonio Lamer (former Chief Justice, Supreme Court of Canada) ${ }^{2}$

* Osgoode Hall Law School, York University; S.J.D. candidate, Faculty of Law, University of Toronto. This article draws from my larger doctoral dissertation on the relations between Indigenous peoples and migrant workers in the context of Canadian immigration law, Aboriginal law, treaty relations, and Indigenous legal traditions. A short version of the article was presented on the emerging scholars panel at the Osgoode Hall 2012 Symposium on 'Re-Igniting Critical Race'. I'm grateful to the symposium organizers, Sujith Xavier and Shanthi Senthe, for inviting me to speak on the panel, my co-panelists for their comments (Carolina Ruiz-Austria, Alejandro Campos, and Adrian Smith), and to the Social Sciences and Humanities Research Council for supporting my doctoral work. Thanks also to the editors, staff, and external reviewers of the Windsor Yearbook of Access to Justice for all of their work. In addition to those above, and those whose work I rely on below, I'd also like to thank the following for their conversations, comments and suggestions on the ideas here: Darlene Johnston, Dawnis Kennedy, Audrey Macklin, Lee Maracle, Meghan Marcil, Tyler McCreary, Shiri Pasternak, Kerry Rittich, and Kim Stanton. All errors are mine.

1 Karl Marx, Capital: A Critique of Political Economy, Vol. 1, transl. (Moscow: Progress Publishers, 1887 [1867]) online: $<$ Marxists.org $>$ at 326.

2 Delgamuukw v British Columbia, [1997] 3 SCR 1010 at para 186 [Delgamuukw]. See also Tsilhqot'in Nation v British Columbia, 2014 SCC 44 (CanLII) online: CanLII <http://canlii.ca/t/g7mt9 $\geq$ at para 82. 
"Sorry, Kiciwamanawak, you're stuck with me."

"In keeping with their respective roles and mandates relating to the temporary entry of foreign workers, Human Resources and Skills Development Canada (HRSDC), Citizenship and Immigration Canada (CIC), and Alberta Learning wish to support employers in the oil and gas sector in meeting requirements that may arise for temporary foreign workers in construction trades during the course of planned construction for projects to develop the Alberta oil sands in Fort McMurray."

Purpose, Memorandum of Understanding for the Entry of Temporary Foreign Workers for Projects in the Alberta Oil Sands

"Canada was built on natural resources; its future will be built on human resources."

The Final Report by Ontario's Expert Roundtable On Immigration (2012)

\section{INTRODUCTION}

Born in Ottawa on unceded Algonquin territory to Canadian immigrants from India and the Philippines, I want to acknowledge the territory where this work took place, which is not just Toronto, but also Tkaronto, a Mohawk or Kanienkehaka word, from one of the languages of the Six Nations that make up the Haudenosaunee Confederacy. Toronto and the surrounding territory is also traditionally of the Huron-Wendat people, the Seneca Nation, and the Anishinaabe, specifically the treaty and traditional territory of the Mississaugas of New Credit. ${ }^{5}$

Racialized immigrants and Indigenous peoples have been in contact as long as Europeans and Indigenous peoples - the history of this relationship is at least as old as African slavery, the migration north by United Empire Loyalists, the building of the railroad by Chinese migrant labourers, and the transnational labour force of the British Empire from South Asia. For example, African interpreter Matthiew da Costa accompanied Pierre du Gua Sieur de Monts (the first French governor of the settlements) to Acadie in $1604{ }^{6}$

3 Harold Johnson, Two families: Treaties and Government (Saskatoon: Purich Publishing Ltd, 2007) at 105.

4 Ontario, Ministry of Citizenship, Immigration and International Trade, Expanding Our Routes To Success: The Final

Report by Ontario Expert Roundtable on Immigration (Toronto: Queen's Park Printer, 2012) online:

$<$ www.citizenship.gov.on.ca/eng-lish/keyinitiatives/imm_str/roundtable/roundtable.pdf $>$.at 60 .

5 See e.g. Victoria Freeman, “'Toronto has no history!' Indigeneity, Settler Colonialism, and Historical Memory in Canada's Largest City" (2010) 38:2 Urban History Review 21; See also Enakshi Dua, "Thinking Through Anti-Racism and Indigeneity in Canada" (2008) 1:1 The Ardent: Anti-Racism \& Decolonization Review 31 at 33. At a recent panel talk on reconciliation and the lack thereof at Massey Hall, Anishinaabe (Pottawatomi \& Ojibway) political scientist Hayden King mentioned that he prefers to acknowledge the territory as the Common Dish in relation to the 1701 treaty of that name (also known as the Bowl with One Spoon Treaty) made between Haudenosaunee and Anishinaabe peoples prior to Confederation. For more on this inter-National treaty, see Amar Bhatia, "The South of the North: Building on Critical Approaches to International Law with Lessons from the Fourth World" (2012) 14 Oregon Review of International Law 131 at 148-9 (with reference to the work of John Borrows and Leanne Simpson on this treaty) [Bhatia, "South of the North"]. For an artistic interpretation of the reiteration of this treaty in the 1764 Silver Covenant Chain, in line with the work of Anishinaabe (Ojibwe) historian Alan Corbiere, see the work of Vanessa Dion Fletcher, "Relationship or Transaction" online: Cargo <http://cargo-collective.com/dionfletcher/Relationship-or-Transaction>. See also Jeff Hewitt, "Reconsidering Reconciliation: The Long View" (2014) 67 SCLR 259.

6 See Paula C Madden, African Nova Scotian - Mi'kmaw Relations (Halifax: Fernwood Publishing, 2009). But see also: 
Most of the early and recent literature that discusses the relationship between racialized immigrants and Indigenous peoples is vertical: that is, their historical and contemporary regulation by the British Crown and then the Canadian state (what Darlene Johnston (Anishinaabe) has called 'Federal populations', e.g. Aboriginals, immigrants, inmates, and the military). ${ }^{7}$ Although not always, such analyses are usually parallel and comparative rather than necessarily looking at interactions where the 'middleman' of the Crown (which can never be entirely cut out) is moved from the foreground to the background of analysis. ${ }^{8}$ This literature is emerging, albeit less so in law. ${ }^{9}$

This article attempts to examine only some of the many issues that arise in discussions about relations between Indigenous peoples and racialized migrants from the global South. First, I review some of the leading debates on anti-racism and decolonization that have been both influential and provocative in academic (and wider) discussions on this topic. Second, I briefly point to some examples of Indigenous-migrant relations that speak to, and complicate, concerns about decolonizing territories, relations, and minds in Canada. Third, I discuss our 'treaty right to be here' and conclude by examining

George Elliot Clarke, “'Indigenous Blacks': An Irreconcilable Identity?” in Ashok Mathur, Jonathan Dewar \& Mike DeGagne, eds, Cultivating Canada: Reconciliation through the Lens of Cultural Diversity (Ottawa: Aboriginal Healing Foundation, 2011); Bonita Lawrence \& Zainab Amadahy, "Indigenous People and Black Canadians: Settlers or Allies?" in Arlo Kempf, ed, Breaching the Colonial Contract: Anti-colonialism in the US and Canada (Dordrecht: Springer Netherlands, 2009) at 105-136.

7 See the excellent article by Heidi Bohaker \& Franca Iacovetta, "Making Aboriginal People 'Immigrants Too': A Comparison of Citizenship Programs for Newcomers and Indigenous Peoples in Postwar Canada, 1940s-1960s" (2009) 90:3 The Canadian Historical Review 427; Rachel Buff, Immigration and the Political Economy of Home: West Indian Brooklyn and American Indian Minneapolis, 1945-1992 (Los Angeles: University of California Press, 2001); Francis Abele \& Daiva Stasiulis, "Canada as a 'White Settler Colony': What about Natives and Immigrants?" in Wallace Clement \& Glen Williams, eds, The New Canadian Political Economy (Kingston: McGill-Queen's University Press, 1989) 240-277; Renisa Mawani, "In Between and Out of Place: Racial Hybridity, Liquor and the Law in Late 19th and Early 20th Century British Columbia" (2000) 15:2 CJLS 9 [ Mawani, "In Between and Out of Place"]. For some of the legal literature, see: Constance Backhouse, Colour-Coded: A Legal History of Racism in Canada, 1900-1950 (Toronto: University of Toronto Press, 1999); James W St G Walker, "Race," Rights and the Law in the Supreme Court of Canada: Historical Case Studies (Toronto: Wilfrid Laurier University Press, 1997); Carol A Aylward, Canadian Critical Race Theory: Racism and the Law (Halifax: Fernwood, 1999).

8 Further relevant work outside of legal scholarship includes: Renisa Mawani, Colonial Proximities: Crossracial Encounters and Juridical Truths in British Columbia, 1871-1921 (Vancouver: University of British Columbia Press, 2009) [Mawani, Colonial Proximities]. Lynne Davis, ed, Alliances: Re/envisioning Indigenous-non-Indigenous relationships (Toronto: University of Toronto Press, 2010); Leanne Simpson \& Kiera L Ladner, eds, This is an Honour Song: Twenty Years Since the Blockades, An Anthology of Writings on the 'Oka Crisis' (Winnipeg: Arbeiter Ring, 2010); Suzanne Mills \& Tyler McCreary, "Social Unionism, Partnership and Conflict: Union Engagement with Aboriginal Peoples in Canada" in Stephanie Ross \& Larry Savage, eds, Rethinking the Politics of Labour in Canada (Halifax: Fernwood, 2012). More recently, see: Anna Stanley, Sedef Arat-Koc, Laurie K. Bertram, and Hayden King, "Addressing the Indigenous-Immigration 'Parallax Gap"” online < antipodefoundation.org/2014/06/18>.

$9 \quad$ For examples in the American legal literature, see Daniel Kanstroom, Deportation Nation: Outsiders in American History (London: Harvard University Press, 2007); T Alexander Aleinikoff, Semblances of Sovereignty: The Constitution, the State, and American Citizenship (Cambridge, MA: Harvard University Press, 2002); Joseph W Singer, "Original Acquisition of Property: From Conquest and Possession to Democracy and Equal Opportunity" (2010) Harvard Public Law Working Paper No. 10-28 online: SSRN <http://ssrn.com/abs-tract=1587363)>; Joseph W Singer, "Titles of Nobility: Property, Poverty, and Immigration in a Free and Democratic Society" (2013) Harvard Public Law Working Paper No. 13-32 online: SSRN <http://ssrn.com/abs-tract=2315091>. More recently, see Leti Volpp, "The Indigenous as Alien" (2015) 5 UC Irvine L Rev 289. 
how Indigenous laws and legal traditions could help to 'decolonize' this right and might open some of the borders that we keep in our minds about these issues. Ultimately, I argue that we can all be treaty people in relations with one another, but only if we are all here to stay.

I also want to note that my use of the five introductory quotations above is an attempt to 'cut the long story short' by showing how people supposedly talking about the same things can do so in very different ways, in an equally wide range of registers. If these quotations are too apocryphal, then the longer story is what follows. The question guiding much of that story seems straightforward enough: what is our right to be here?

\section{DECOLONIZATION, THE COMMONS, AND GOLDILOCKS CITIZENSHIP}

Encapsulating, in part, larger conversations and debates, the two articles I focus on here are both concerned with decolonization. Published in 2005, Bonita Lawrence (Mi'kmaw) and Ena Dua's article "Decolonizing Antiracism" found a reply from Nandita Sharma and Cynthia Wright in their 2008 article, "Decolonizing Resistance, Challenging Colonial States". ${ }^{10}$ In the former, Lawrence \& Dua set out to interrogate a brand of liberal, multiculturalist, and disempowering pluralism that they see as an exclusionary feature of contemporary Canadian antiracism. Their starting point at the confluence of indigeneity and antiracism is also, arguably, at the horizon of liberal approaches ${ }^{11}$ and even left-legal ${ }^{12}$ (or treaty rights) analyses of the respective rights of both migrants and Indigenous peoples. ${ }^{13}$ Indeed, Lawrence \& Dua note that: "Aboriginal people cannot see themselves in antiracism contexts, and Aboriginal activism against settler domination takes place without people of color as allies"; avoiding such segregated activism would mean that postcolonial/antiracism theorists "begin to take Indigenous decolonization seriously". ${ }^{14}$ Both authors proceed to situate their work with and impressions of antiracism, but as an immigrant from India, Dua's initial comments are especially interesting in the context of migration in a settler-colonial context. Dua writes that:

My approach in this article, as someone committed to antiracist feminist struggles, is to examine my complicity in the ongoing project of colonization. My complicity is complex. First, as an inhabitant of Canada, I live in and own land that has been appropriated from Aboriginal peoples. As a citizen of Canada, I have rights and privileges that are denied to Aboriginal peoples collectively, and that are deployed to deny Aboriginal rights to self-government. Second, as someone involved in antiracist and progressive struggles, I wonder about the ways in which the bodies of knowledge that I have worked to build have been framed so

10 Bonita Lawrence \& Enakshi Dua, "Decolonizing Antiracism” (2005) 32 Social Justice 4 at 120; Nandita Sharma \& Cynthia Wright, "Decolonizing Resistance, Challenging Colonial States" (2008/2009) 35 Social Justice 3 at 120 [Sharma \& Wright, "Decolonizing Resistance"].

11 This point is developed further in my dissertation, but for the most prominent example, see Will Kymlicka, Multicultural Citizenship: A Liberal Theory of Minority Rights (Oxford: Clarendon, 1995) at 14-17.

12 On left-legal analysis, see e.g. Linda Bosniak "Being Here: Ethical Territoriality and the Rights of Immigrants" (2007) 8 Theor Inq L 389; On treaty rights, see Johnson, supra note 3.

13 For related work, see Amar Bhatia "South of the North" supra note 5, and Amar Bhatia, "In A Settled Country, Everyone Must Eat': Four Questions About Transnational Regulation, Migration, and Migrant Work” (2012) 13 German Law Journal, online: German Law Journal <www.germanlawjournal.com/index.php?pageID=11\&-artID=1479)> [Bhatia, "In A Settled Country"] .

14 Lawrence \& Dua, supra note 10 at 120. 
as to contribute to the active colonization of Aboriginal peoples.

Dua's recognition of her potentially colonizing presence on the land, and the implications for her right to be here, are likely not the norm for most immigrants and 'new' or 'old' Canadians. Due to the erasure of Indigenous peoples and colonization from much of the international and Canadian literature on antiracism and postcolonial theory, Lawrence \& Dua conclude that "antiracism is premised on an ongoing colonial project". ${ }^{15}$ They note that this project takes place at both theoretical and practical levels, but that ultimately they seek a possible dialogue between antiracist and Aboriginal activists, which would break the complex complicity of marginalized immigrants whose efforts at becoming full citizens inevitably partakes of ongoing colonialism. ${ }^{16}$ This dialogue would ideally take place at the intersection of people and policies across Canada, whether with respect to homogenizing discourses (e.g. the removal of Japanese boats and Aboriginal fishing rights) or 'heterogenizing' developments (black/Mi'kmaw intermarriage). ${ }^{17}$

Despite acknowledging the differences amongst slaves, migrant workers, refugees, and émigrés, Lawrence \& Dua nonetheless note: "People of color are settlers [... who] live on land that is appropriated and contested, where Aboriginal peoples are denied nationhood and access to their own lands". ${ }^{18}$ The parallel history of settlement on 'freed up'/dispossessed land that they review encompasses: Nova Scotia black loyalists, which erases Mi'kmaw/Wabanaki resistance; focus on 'head tax' restrictions that effaces post-1885 Cree and Blackfoot suppression; the adoption of 'colonist' mentality or practice by South Asian, Japanese, and Jewish immigrants to fit the white settler norm; and, the potential voting patterns of citizens of colour on the failed Charlottetown Accord recognizing, among other things, a 'third order' of Aboriginal government. ${ }^{19}$ However, Lawrence \& Dua direct particular attention to the problems of immigration and the attempted erasure of Indigenous people by multiculturalism as an official policy (which they note was promulgated at the same time as Trudeau's infamous 1969 White Paper/Indian Policy). They are quite wary of statist immigration policy and 'open borders' arguments as hurdles to Aboriginal rights:

Regarding immigration, Aboriginal peoples are caught between a rock and a hard place. Either they are implicated in the anti-immigrant racism of white Canadians, or they support struggles of people of color that fail to take seriously the reality of ongoing colonization. Often overlooked by antiracist activists is that

$15 \quad$ Ibid at 123.

16 Ibid at 133; For a discussion on the difference between complicity and privilege in this context, see Beenash Jafri, "Privilege vs. Complicity: People of Colour and Settler Colonialism" (21 March 2012) online: Ideas Can

$<$ http://www.ideas-idees.ca/blog/privilege-vs-complicity-people-colour-and-settler-colonialismx $>$. See also: Shaista Patel, "Defining Muslim Feminist Politics through Indigenous Solidarity Activism" The Feminist Wire (1 August 2012) online: Feminist Wire <http://thefeministwire.com/2012/08/defining-muslim-feminist-politics-through-indigenoussolidarity-activism/>. More generally, see also Patricia Williams in this special issue, and Mary Louise Fellows and Sherene Razack, "The Race to Innocence: Confronting Hierarchical Relations among Women" (1998) 1 J Gender Race \& Just 335 .

17 Lawrence \& Dua, supra note 10 at 136; Excellent examples of the type of scholarship desired by Lawrence \& Dua would be Buff; and Bohaker \& Iacovetta, supra note 7; Mawani, supra note 8; and Volpp, supra note 9. See also: Harsha Walia, Undoing Border Imperialism (Oakland: AK Press, 2013).

18 Lawrence \& Dua, supra note 10 at 134.

19 Ibid at 134-135. 
the Delgamuuk'w decision clearly set out instances in which Aboriginal title could be infringed (i.e., limited or invalidated) by continuing immigration. Canada's immigration goals, then, can be used to restrict Aboriginal rights. Antiracist activists need to think through how their campaigns can preempt the ability of Aboriginal communities to establish title to their traditional lands. Recent tendencies to advocate for open borders make this particularly important. Borders in the Americas are European fictions, restricting Native peoples' passage and that of peoples of color. However, to speak of opening borders without addressing Indigenous land loss and ongoing struggles to reclaim territories is to divide communities that are already marginalized from one another. The question that must be asked is how opening borders would affect Indigenous struggles aimed at reclaiming land and nationhood. ${ }^{20}$

Lawrence \& Dua's concerns are obviously not unfounded. Indeed, most migrant rights' advocacy or immigration law scholarship adopts policy solutions and points of departure that do not centre Indigenous decolonization. ${ }^{21}$ In one of the recent leading works in immigration law by a scholar I greatly admire, the issue of pre-existing communities with attachments to the land as a basis for grounding immigrant rights is relegated (largely unfavourably) to a footnote. ${ }^{22}$

Nandita Sharma and Cynthia Wright have undertaken some of this work by responding to Lawrence \& Dua. ${ }^{23}$ As with Lawrence \& Dua, Sharma \& Wright seek to go beyond the liberal maintenance or left

20 Ibid at 136, notes omitted; On the settlement of foreign populations (and resource extraction, infrastructure development) as justifiable limits on Aboriginal rights, see: Delgamuukw, supra note 2 at para 165 (citing R. v Gladstone [1996] 2 SCR 723, at para 73). Also, see Kim Stanton, Truth Commissions and Public Inquiries: Addressing Historical Injustices in Established Democracies (SJD thesis, University of Toronto, 2010) citing Mark D Walters, "The Jurisprudence of Reconciliation: Aboriginal Rights in Canada." in W Kymlicka \& B Bashir, eds, The Politics of Reconciliation in Multicultural Societies (Oxford: Oxford University Press, 2008) 165 at 182.

21 See e.g. Joseph Carens, "Aliens and Citizens: The Case for Open Borders" (1987) 49:2 The Review of Politics 251; Donald Galloway, "Strangers and Members: Equality in an Immigration Setting” (1994) 7 Can JL \& Jur 149; Howard Chang, "The Economics of International Labor Migration and the Case for Global Distributive Justice in Liberal Political Theory (2007) 40 Cornell Int'l LJ. Leti Volpp highlights the dearth of Indigenous peoples in the U.S. immigration law teaching and scholarship context, Volpp, supra note 9. This absence is confirmed at the more general level of law textbooks approved for use in Ontario secondary schools (see Amar Bhatia, "What Happens to All of Us: Depictions and omissions of Indigenous peoples, nations, and laws in secondary school law textbooks approved for use in Ontario, 1930-2013" (on file with author)) [Bhatia, "What happens to all of us"].

22 Bosniak, supra note 12 (Bosniak generally advances 'ethical territoriality' or mere territorial presence as the best argument for immigrant rights, and definitely better than relying on formal immigration status for recognition) at 405 , note 41 ("An 'attachment to the land' concept does not seem to support the ethical territorial position, because it presupposes an already-existing membership community that maintains an ongoing relationship with the land in question. The ethical territorial view is far more open, holding that the fact of presence within the state's borders, even if or recent vintage, is itself the basis for community membership."). Although tangential to her main argument (which indirectly confirms the absence of Indigenous peoples in immigration law), Bosniak does seem to reinforce the assumption that communities with attachments to the land cannot simultaneously have relationships with newcomers, settlers, im/migrants. I develop this point at greater length in my doctoral dissertation.

23 Sharma \& Wright, "Decolonizing Resistance", supra note 10 at 120-121. Other relevant work by Sharma includes: Nandita Sharma, Home Economics: Nationalism and the Making of Migrant Workers in Canada (Toronto: University of Toronto Press, 2006) [Sharma, Home Economics]. See also Bridget Anderson, Nandita Sharma, \& Cynthia Wright, "Editorial: Why No Borders?" (2009) 26:2 Refuge 5; Craig Fortier, "No One Is Illegal Movements and Anti-colonial Struggles from within the Nation-State" in Luin Goldring \& Patricia Landolt, eds, Producing and Negotiating NonCitizenship: Precarious Legal Status in Canada (Toronto: University of Toronto Press, 2013) at 274-290. More recently, see Nandita Sharma, 'Migrants and indigenous nationalism' in Steven J Gold \& Stephanie J Nawyn, eds, Routledge International Handbook of Migration Studies (New York: Routledge, 2013). 
reform of the state and, in fact, they hope to shed the structural violence and exclusions inherent to the state form altogether. They contest the equation of 'people of color with settlers' and instead emphasize the plurality of migrations that have come to constitute contemporary Canada (i.e. Indigenous, colonizer, settler, immigrant, migrant, development-displaced). They especially challenge Lawrence \& Dua's supposed conflation of both migration with settler colonialism and decolonization with Indigenous nationalism. ${ }^{24}$ They make specific criticism of the globalized neoliberal tendencies of Lawrence \& Dua's linkage of migration-as-colonization/indigenous nationalism-as-decolonization by analogizing it to European neo-racism (e.g. European white native restrictions on migration/naturalization). ${ }^{25}$ However, this anti-nationalism in turn seems to conflate Indigenous nationalism with modernist or etatist nationalism, which seems inaccurate and overstates an argument that is perhaps better made in distinguishing people of colour from settler colonists. ${ }^{26}$ Nonetheless, Sharma \& Wright argue that Lawrence \& Dua's denials of solidarity also deny “...the back-story to how so many 'Natives' and 'nonNatives' ended up with one another [...] the fact that modern colonization largely depended on the global mobilization of the newly expropriated and soon-to-be exploited proletarians". ${ }^{27}$ Indeed, after noting some of the complexities, fractures, and failures of Latin American indigenous etatism, Sharma \& Wright instead emphasize the need to decolonize relationships rather than merely territories. ${ }^{28}$ Ultimately, the relational decolonization that they propose points to the goal of global commons ${ }^{29}$ and the process of commoning. In grounding their proposed alternatives to Lawrence \& Dua's starting point of fracture, Sharma \& Wright favour commons and rights to the commons as the test for allies. ${ }^{30}$ One example of such bridge-building for paradigm change they mention are the transnational Indigenous migrants who travel from Mexico to work in the United States. ${ }^{31}$

The discussion raised by Lawrence \& Dua and Sharma \& Wright reiterates some of the recurring questions at the heart of my larger doctoral work. At first blush, it is clear that there are no automatic solidarities between 'Indians' and 'Aliens ${ }^{32}$, but instead that these relationships must be forged,

24 On this point, Sharma \& Wright, "Decolonizing Resistance", supra note 10, refer to Vijay Prashad, The Darker Nations: A People's History (New York: New Press, 2007) and the failure of the Third World Project in the cocktail of sovereignty and global capitalism, yielding the current desire for decolonization without nationalism. Sharma \& Wright, "Decolonizing Resistance", supra note 10 at 123-125; Cf Jace Weaver, Craig S Womack, \& Robert Warrior, American Indian Literary Nationalism (Albuquerque: University of New Mexico Press, 2006), esp. ch 3.

26 Also, see Taiaiake Alfred, Peace, Power, Righteousness: An Indigenous Manifesto (Toronto: Oxford University Press, 1999). See also Johnson, supra note 3 (highlighting ongoing relationships for treaty and non-treaty nations rather than seeking termination).

27 Sharma \& Wright, "Decolonizing Resistance", supra note 10 at 126.

28 Ibid at 130; Along similar lines see e.g., Courtney Jung, The Moral Force of Indigenous Politics: Critical Liberalism and the Zapatistas (New York: Cambridge University Press, 2008).

29 Sharma \& Wright, "Decolonizing Resistance", supra note 10 at 130; $C f$ international law's history of global commons, e.g. Boaventura de Sousa Santos, Toward a New Common Sense: Law, Science and Politics in the Paradigmatic Transition (New York: Routledge, 1995); Karin Mickelson, "Co-Opting Common Heritage: Reflections on the Need for South-North Scholarship" in Obiora Chinedu Okafor \& Obijiofor Aginam, eds, Humanizing Our Global Order: Essays in Honour of Ivan Head (Toronto: University of Toronto Press, 2003) at 112-124.

30 Sharma \& Wright, "Decolonizing Resistance", supra note 10 at 143

31 Ibid at 142; See also Jonathan Fox \& Gaspar Reivera-Salgado, Indigenous Mexican migrants in the United States (La Jolla, CA: University of California San Diego, Center for Comparative Immigration Studies, 2004); Lynn Stephen, Transborder lives: Indigenous Oaxacans in Mexico, California, and Oregon (Durham: Duke University Press, 2007).

32 See ss 91(24) and (25), British North America Act, 1867, 30 \& 31 Victoria, c 3 (UK). 
maintained, storied, and revisited. As noted in a book chapter by Zainab Amadahy and Bonita Lawrence:

One of the questions that emerge from the work described above must be posited to Indigenous peoples: Where do racialized settlers fit in the vision of Indigenous sovereignty? For the purposes of this chapter we need to ask where Black people fit into the vision. This is a huge question. If Indigenous sovereigntists expect Black community support of nation-to-nation negotiation processes regarding land, resources, and reparations, we have to recognize how Blacks become completely disempowered in that process. [...]

This challenges grassroots Indigenous leadership to develop a vision of sovereignty and self-government that addresses the disempowered and dispossessed from other parts of the world who were forced and/or coerced into being here on Turtle Island (a global phenomenon in which Canada shares culpability). How much support should be expected from communities when there are glaring examples in our midst, such as the expulsion of Black Cherokees in Oklahoma, that there is no guarantee that Black Indians and Black people who lend their support to Indigenous communities will have a place in or beside them? ${ }^{33}$

The real tension of the questions raised by Amadahy \& Lawrence speaks to the stakes of any potential solutions. Although Sharma \& Wright's desire for commoning is appealing in principle, it raises some lingering questions (as would any proposal). In emphasizing an anti-globalization tactic (against neoracism and neoliberalism) via 'commoning', Sharma \& Wright potentially focus upon a version of an 'end to history'. 34

These issues have been raised in part, amongst states historically, through the global commons (and common pool resources) at international law, namely: Antarctica, the high seas and deep seabed minerals, the atmosphere, and outer space (including principles such as the common heritage of mankind). ${ }^{35}$ More germane to the particular questions of status, authority, and our right to be here already raised, however, is the political and economic project of the commons. To reiterate, and adapting from Peter Linebaugh's 2008 book, The Magna Carta Manifesto, ${ }^{36}$ Sharma \& Wright propose

33 Lawrence \& Amdahy, supra note 6 at 130-131. As discussed below, they also address the framework of the Two Row Wampum for settler-Indigenous co-existence on Turtle Island and how questions arise concerning coexisting with the Canadian state and its ideology at 131 .

34 This debate mirrors that found in more 'traditional' approaches to immigration law, which focus on the distinctions found between liberal nationalism and ethical cosmopolitanism. See e.g. Linda Bosniak, "Citizenship Denationalized" (2000) 7:2 Ind J of Global Leg Stud 447 at 498-502; Seyla Benhabib, The Rights of Others: Aliens, Residents and Citizens (Cambridge: Cambridge University Press, 2004); Kwame Anthony Appiah, Cosmopolitanism: Ethics in a World of Strangers 1st ed (New York: WW Norton, 2006). See also Carly Austin \& Harald Bauder, “Jus Domicile: A Pathway to Citizenship for Temporary Foreign Workers?” (2010) Centre Européen de Recherches Internationales et Stratégiques Working Paper No 81, online: CERIS < http://www.ceris.metropolis.net/wpcontent/uploads/pdf/research_publication/working_papers/wp81.pdf $>$.

35 See de Sousa Santos, supra note 30 at 365-373. For an excellent discussion on the common heritage of mankind, and how it cannot be ethically divorced from its Third World origins. See Mickelson, supra note 30.

36 Peter Linebaugh, The Magna Carta Manifesto: Liberties and Commons for all (Berkeley: University of California Press, 2008). But see JM Neeson, Commoners: Common Right, Enclosure and Social Change in Common-Field England, 1700-1820 (New York: Cambridge University Press, 1993); JM Neeson, “Commons' Sense: The Failure and Success of British Commons" (Plenary paper delivered at Property and Commons International Seminar, Paris, 25 April 2013) online <http://www.mshparisnord.fr/ANR-PROPICE/25-26_avril/neeson_british-commons.pdf $>$ (reflecting on the two examples of commons in her paper, Neeson notes that “... they survived best where the right to use them, while regulated, was also widely enjoyed; title to them was secure; landowners, commoners and regulators were the same 
to decolonize both territories and relations through a process of commoning in order to achieve the goal of a global commons (distinct from the inter-state international law sense) ${ }^{37}$ and in opposition to enclosures and private property. The four principles of commoning require embedding the decolonization of relations in: 1) the local ecology, without being essentialist; 2) the labour process, so that the commons is entered into through labour; 3) a collective process, and 4) processes that are independent of the state and the law, operating without sovereigns and instead relying on the principles of neighbourhood, subsistence, travel, anti-enclosure, and reparations. ${ }^{38}$ As noted, although the goal is a worthy one, the means for achieving it raise some questions. ${ }^{39}$ For instance, given the historical concentration of most im/migrants potentially encompassed by commoning in and around Montreal, Toronto, Vancouver, and (more recently) cities and employers in the Prairies, it is not clear which labourers or principles would govern the rest of the post-Canadian commons. The lack of labourers or principles outside of the traditional immigration magnets is especially striking in a context meant to be embedded in local ecology through collective processes, yet without the input of Indigenous peoples, nations or legal traditions.

Another key question is whether labour should be the only grounds for entering the commons, especially where the distinctions between what has been productive, versus unproductive, versus reproductive, will likely not disappear on their own in the absence of the state and/or law. ${ }^{40}$ Indeed, these divisions have structured the colonial legacy and dispossession (through prescription and alienation) of Indigenous lands through contested but consequential notions of productive agriculture by positively mobile settlers (Lockean labour mixed with the land) and unproductive seasonal rounds by negatively mobile Indigenous peoples. ${ }^{41}$ The work of familial and social reproduction has been a similar source of division, control, and precarity domestically ${ }^{42}$ and with respect to migration, as evidenced by

people; and where the wider community understood the value and, indeed, the necessity of the commons" (notes omitted)).

37 Cf Mickelson, supra note 30 at 118-119 (re Bedjaoui, Common Heritage of Mankind, and the attempt at worldwide solidarity by extending the concept to resources within national sovereignty e.g. oil).

38 See Sharma \& Wright, "Decolonizing Resistance", supra note 10 and the original in Linebaugh, supra note 37.

39 See also Bridget Anderson, Nandita Sharma \& Cynthia Wright "We Are All Foreigners: No Borders as a practical political project" in Peter Nyers \& Kim Rygiel, eds, Citizenship, Migrant Activism and the Politics of Movement (New York: Routledge, 2012) at 85-86 (for another iteration of this argument for the commons and common rights to travel and stay, among others, as part of the authors' proposal for 'no borders' in the immigration context).

40 On a related point see Bhatia, “In A Settled Country”, supra note 13 at notes 36-37 (re Jennifer Gordon's proposal for transnational labour citizenship and Leah Vosko's critique of its own ‘borders' and inaccessibility).

41 See e.g. John Locke, Two Treatises of Government, ed. Thomas Hollis (London: A. Millar et al., 1764) online $<$ http://oll.libertyfund.org/titles/222> at ch. 4, § 24-45; John C Weaver, "Concepts of Economic Improvement and the Social Construction of Property Rights: Highlights from the English-Speaking World” in John McLaren, A.R. Buck, \& Nancy E. Wright, Despotic dominion: property rights in British settler societies (Vancouver: UBC Press, 2004); Rob Nixon, Slow Violence and the Environmentalism of the Poor (Cambridge: Harvard University Press, 2013).

42 See e.g. Janet Halley and Kerry Rittich, "Critical Directions in Comparative Family Law: Genealogies and Contemporary Studies of Family Law Exceptionalism" (2010) 58 American Journal of Comparative Law 753 at $756-758$ (Halley \& Rittich work from a definition of modern household used by systems theorists Immanuel Wallerstein and Joan Smith, i.e. "a human association bounded through social negotiation and aimed at securing human reproduction, including reproduction from day to day of its members as well as the production of new human beings. In liberal economic orders, it is an importance source of social security. In modern capitalism, it is a crucial site of consumption" in 'Households as an Institution of the World-Economy' in Wallerstein \& Smith, eds., Creating and Transforming 
the treatment of racialized, so-called low-skill migrant workers and their membership (or lack thereof) in Canadian society, whether as domestic workers, service workers, or farmworkers. ${ }^{43}$ There is no guarantee that a move to the practice of commoning would avoid what I would call 'Goldilocks' or 'Just Right' citizenship. Currently, this 'goldilocks citizenship' casts some people (such as Indigenous peoples) as having been here too long, while others (such as migrant workers) are seen as not having been here long enough, and still more are just right or have been here long enough to be the authorities on citizenship and belonging. ${ }^{44}$ And the measure of what makes them 'just right' is whether their work has been accorded staying power in the economy, by the state, in stories, or in law, as part of a productive and profitable struggle against nature and unimproved land, set apart from women and the home, and against the wrong kinds of mobility. Goldilocks citizenship does not encompass the mobility of seasonal rounds or movement across traditional territories by Indigenous peoples and nations. ${ }^{45}$ Magically, it also does not arise from some who mix their labour with the soil, at least in the case of migrant farm workers who gain neither property nor citizenship status from the sweat of their brows. ${ }^{46}$

As seen from the above, different frames of work and mobility determine legal and political standing in relation to the land and, in turn, whose economies, polities, and societies get to be reproduced both now and later (whether in a pre- or post-commons Canada). These issues relate to the struggles of both Indigenous peoples and migrant workers and would need to inform processes of global commoning beyond a general entry via labour. Interestingly, historian Peter Linebaugh focuses on a variety of contributors to a history and future of commoning in North America and beyond, including Indigenous peoples:

Commoning as associated with Indians, African Americans, industrial workers, and women has on occasion alluded to Magna Carta, so we have a double task - to reveal how commoning has been exercised

Households: the Constraints of the World Economy (1992)).

43 See e.g. Sedef Arat-Koc, "In the Privacy of Our Own Home: Foriegn Domestic Workers as Solution to the Crisis of the Domestic Sphere in Canada" (1989) 28 Studies in Political Economy 33; Audrey Macklin, "Foreign Domestic Worker: Surrogate Housewife or Mail Order Servant?" (1992) 37 McGill LJ 681; Abigail Bakan \& Daiva Stasiulis, eds, Not One of the Family: Foreign Domestic Workers in Canada (Toronto: University of Toronto Press, 1997); Sharma, Home Economics, supra note 24; Salimah Valiani, "The Shifting Landscape of Contemporary Canadian Immigration Policy: The Rise of Temporary Migration and Employer-Driven Immigration" in Luin Goldring \& Patricia Landolt, eds., Producing and Negotiating Non-Citizenship: Precarious Legal Status in Canada (Toronto: University of Toronto Press, 2013). More recently, see Ethel Tungohan, "From 'Migrant' to 'Citizen': Learning from the Experiences of Former Caregivers Transitioning out of the Live-in Caretiver Program” Gabriela Transitions Experiences Survey (GATES) Preliminary Analysis (July 22, 2014) online <http://www.gatesurvey.com/wp-content/uploads/2014/07/GATESPreliminary-Analysis-201407221.pdf >; Caregivers' Action Centre, 'Access to Permanent Residency limited under new Government Rules’ (November 12, 2014) online < http://caregiversactioncentre.org/access-to-permanent-residencylimited-under-new-government-rules/>.

44 For similar points with respect to Indigenous peoples, see also Nixon, supra note 41 at 165, 243 ('Resource Law of Inverse Longevity'); John Borrows, "Physical Philosophy: Mobility and the Future of Indigenous Rights" in Benjamin J Richardson, Shin Imai \& Kent McNeil, eds, Indigenous Peoples and the Law: Comparative and Critical Perspectives (Oregon: Hart Publishing, 2009) at 403 (the 'too settled' thesis) [Borrows, "Physical Philosophy"].

45 See e.g. Borrows, ibid.

46 See e.g. Adrian Smith, "Racialized In Justice: The Legal and Extra-Legal Struggles of Migrant Agricultural Workers in Canada" in this issue. More generally, see, Aziz Choudry \& Adrian Smith, eds, Unfree Labour? Struggles of Migrant and Immigrant Workers in Canada (forthcoming, 2015). 
in the American past and what Magna Carta has meant. We can uncover in that history the five principles of Magna Carta's commons, namely, anti-enclosure, reparations, subsistence, neighborhood, and travel. ${ }^{47}$

Indeed, Linebaugh goes so far as to note that the "anti-enclosure struggles of Native Americans are fundamental to the ecology and landscape of American history" ${ }^{48}$ Relatedly, it is worth noting here that historian Alan Greer cautions against romanticizing the commons, since he argues that the enclosure of America by colonizers took place as a form of commoning in the context of a clash between Indigenous and colonial commons, leading to the dispossession of the former. ${ }^{49}$ However, without pre-judging the matter, it is precisely this clash and competition of commons that must be examined. Clearly, whether that of Sharma \& Wright, Linebaugh, Neeson, or Greer, there is no version of communing that will be free from conflict. And if, as noted by Marx above, ${ }^{50}$ the original sources of all wealth are the worker and the soil, or the labourer and the land, then the redistribution sought through commoning, and on behalf of workers, migrant workers, and Indigenous peoples, also must contend with the issue of the treaties, which underpin workers' status as well as grant access to supposedly shared lands.

One element that runs through the foregoing debate, and many of the referenced authors, is uncertainty about Indigenous nations, laws, and legal traditions and acknowledging them as sources of authority. ${ }^{51}$ The next section of this article examines some of these controversies, both real and speculative, about Indigenous authority over immigration. The final section and conclusion of the article attempt to advance a more optimistic interpretation, where future attempts at decolonizing territories and relations need not necessarily rely solely on decontextualized commoning or completely open borders or no borders, given their respective histories of violence and current neoliberal economic globalization. ${ }^{52}$ Instead, Indigenous legal traditions of hospitality through adoption and treaty might be among the many local and grounded ways that these recurring questions of borders, sovereignty, and membership might be more fruitfully addressed here and in the global contexts that contribute to our local constructs. ${ }^{53}$

47 Linebaugh, supra note 36 at 245 (see also Chapter 11).

48 Ibid at 249.

49 Allan Greer, "Commons and Enclosure in the Colonization of North America" (2012) 117 American Historical Review 365. More recently, see Daniel Rueck, "Commons, Enclosure, and Resistance in Kahnawá:ke Mohawk Territory, 18501900" (2014) 95:3 The Canadian Historical Review 352-381. See also, G Caffentzis, "The future of 'the commons': Neoliberalism's 'plan B' or the original disaccumulation of capital?" (2010) 69 New Formations 23; Ben Maddison, "Radical commons discourse and the challenges of colonialism" (2010) 108 Radical History Review 29; Neeson supra note 36.

50 Marx, Capital, supra note 1, Vol. I. See also: Brett Clark \& Richard York, "Rifts and Shifts: Getting to the Root of Environmental Crises" (2008) 60 Monthly Review.

51 See Lawrence \& Amadahy, supra note 6 at131. See also Bhatia, "What happens to all of us", supra note 22. More generally, see John Borrows, Canada's Indigenous Constitution (Toronto: University of Toronto Press, 2010) at 231-232 [Borrows, Canada's Indigenous Constitution]

52 See e.g. Mickelson, supra note 30, Greer et al. supra note 49. See also: Antony Anghie, "Francisco de Vitoria and the Colonial Origins of International Law" (1996) 5:3 Soc \& Leg Stud 321; Martti Koskenniemi, "Empire and International Law: the Real Spanish Contribution" (2011) 61:1 UTLJ 1; and Georg Cavallar, The Rights of Strangers: Theories of International Hospitality, the Global Community, and Political Justice since Vitoria (Aldershot: Ashgate, 2002).

53 See also Bhatia, "South of the North", supra note 5 and Bhatia, "In A Settled Country", supra note 13. 


\section{STORIES OF EXCLUSION \& BELONGING: NOT ONE OF THE TWO FAMILIES}

What would Indigenous authority over immigration look like, and how might these visions speak to some of the tensions, potential conflicts, and uncertainties raised above?

Here is one of the worst-case scenarios: the government consults (whether voluntarily or according to the duty to consult required by the 'honour of the Crown') with Aboriginal peoples over the mix and levels of immigration to Canada, with the reported result being a general desire to maintain or reduce immigration targets, followed by a sprinkling of dated quotes or discarded resolutions by Aboriginal leaders about supposedly closing the borders or freezing immigration until the government meets its existing responsibilities. ${ }^{54}$ The exclusionary sentiments from such a seemingly 'ground breaking' neoliberal federal consultation with First Nations on immigration fits the fearful vision of Indigenous nationalism mentioned above. But for Indigenous peoples, the much longer-running exclusions arising consequent to family decisions under the Indian Act are more than just a vision; they are a reality. While not usually considered 'immigration', this reality is clear in the issue of kinship and the 'invidious' historical marrying-out and current 'second-generation cut-off' provisions of the Indian Act and delegated and devolved decision-making over band membership and Indigenous National citizenship codes. ${ }^{55}$ Apart from its 'Indian' policies, the issue of migration as kinship migration looms large in the Canadian state's external immigration policies as well. ${ }^{56}$ However, these Indian Act tactics are also the product of the Crown and the state's avowed policy and strategy of assimilation and 'extinction by numbers' ${ }^{57}$ through existing and proposed Aboriginal legislation, whether in the Indian Act or proposed pushes to privatize reserve lands as alienable 'fee simple' title lands ${ }^{58}$. Even more so, these policies are also the Canadian state's active foreclosure of the self-determination of Indigenous nations and communities and, ultimately, their ability to survive and reproduce themselves socially and politically (as Canada does) through inter-marriage, procreation, and immigration.

To counter-balance these worst-case scenarios, it is worth returning to a point raised by Lawrence \& Dua about the Delgamuukw decision and how the 'settlement of foreign populations' or immigration can be used to infringe on Aboriginal title, as well as the point by Sharma \& Wright about the global mobilization of expropriated and exploited proletarians. From the perspective of the Supreme Court of Canada, 'attachment to the land' is a powerful and determinative phrase and concept in the realm of Aboriginal title and rights ("... the nature of the attachment to land which forms the basis of the

54 "First Nations consulted on 2013 immigration targets as Tories break new ground" Prince Albert Daily Herald (20 September 2012); $c f$ Xavier Kataquapit, "Most came to Canada as immigrants" Timmins Press (10 October 2012).

55 See e.g. Pamela Palmater, Beyond blood: Rethinking Indigenous Identity (Saskatoon: Purich Publishing, 2011); John Borrows, Seven Generations, Seven Teachings: Ending the Indian Act (Vancouver: National Centre for First Nations Governance, 2008); Val Napoleon, "Extinction by Number: Colonialism Made Easy" (2001) 16:1 CJLS 111 [Napoleon, "Colonialism Made Easy"].

56 On kinship immigration in the Canadian context, see Bhatia, "In A Settled Country", supra note 13, citing Audrey Macklin. See also Bakan \& Stasiulis, supra note 44 (on the preservation of the domestic Canadian family at the expense of the transnational Filipina household).

57 Napoleon, "Colonialism Made Easy, supra note 56.

58 See e.g. Thomas Flanagan, Christopher Alcantara \& Andre Le Dressay, Beyond the Indian Act, Restoring Aboriginal Property Rights (Kingston: McGill-Queen's University Press, 2010). But see Shiri Pasternak, "How Capitalism Will Save Colonialism: The Privatization of Reserve Lands in Canada" (2014) Antipode 1. 
particular group's aboriginal title") $)^{59}$. Writing about then-Chief Justice Lamer's comments on the meaning of Aboriginal title in the Delgamuukw decision, Kent McNeil notes that Lamer C.J. rejected the notion that Aboriginal title was merely a license to use and occupy land or that its content was limited to traditional uses of the land. ${ }^{60}$ The test for justifying infringement of Aboriginal rights has two parts: furtherance of a compelling and substantial legislative objective and whether or not the infringement is consistent with the special fiduciary relationship between the Crown and Aboriginal peoples. Citing $R$. v. Gladstone, ${ }^{61}$, Lamer C.J. notes that there is a "fairly broad" range of objectives that could justify infringing aboriginal title:

In my opinion, the development of agriculture, forestry, mining, and hydroelectric power, the general economic development of the interior of British Columbia, protection of the environment or endangered species, the building of infrastructure and the settlement of foreign populations to support those aims, are the kinds of objectives that are consistent with this purpose and, in principle, can justify the infringement of aboriginal title. Whether a particular measure or government act can be explained by reference to one of those objectives, however, is ultimately a question of fact that will have to be examined on a case-by-case basis. [emphasis added] ${ }^{62}$

Many of these potentially justifiable infringements of Aboriginal title emerge through the extractive industries and the associated need for the migration of labour (within, across and outside of Canada) to support such extraction. ${ }^{63}$ The Supreme Court of Canada has recently confirmed this broad range of justifiable infringements. ${ }^{64}$

With this in mind, who do Indigenous peoples seem to keep out? After all, the image of borders closed by Indigenous peoples to racialized migrants from the global South is not front of mind. Instead, some of the biggest boundaries asserted by Indigenous peoples and nations are not against people, but corporations (and representative governments that are just not that representative). ${ }^{65}$ A short list of blockades and occupations in defence of land, whether on reserve, or treaty, traditional, or unceded territories, includes: Elsipogtog, Aamjiwnang, Tayendinega, Kitchenuhmaykoosib Inninuwug, Algonquins of Barriere Lake, the Haudenosaunee at Caledonia, Secwepmec at Sun Peaks, Mohawks at

59 Delgamuukw, supra note 2 at para 111.

60 Kent McNeil, “Aboriginal Title and the Supreme Court: What's Happening?” (2006) 69 Sask L Review 281 at 287 (citing Delgamuukw, supra note 2). More recently, see K McNeil, “Aboriginal Title in Canada: Site-specific or Territorial?" (2014) 91:3 Can Bar Rev 745.

61 [1996] 2 SCR 723 at para 73.

62 Delgamuukw, supra note 2 at para 165. Lawrence \& Dua, supra note 10 at 136.

63 See e.g. Alberta Memorandum of Understanding for the Entry of Temporary Foreign Workers for Projects in the Alberta Oil Sands. For migrations from the Atlantic provinces, from outside of Canada, and by Indigenous workers, see, respectively Nelson Ferguson, "From Coal Pits to Tar Sands: Labour Migration between an Atlantic Canadian Region and the Athabasca Oil Sands" (2011) 17 Just Labour 106; Jason Foster \& Alison Taylor, "In the shadows: Exploring the notion of 'Community' for temporary foreign workers in a boom town" (2013) 38:2 Canadian Journal of Sociology 167; Lindsay A Bell, "In Search of Hope: Mobility on the Canadian Frontier" in W Lem \& P Gardiner-Barber, eds, Migration in the 21st Century: Ethnography and Political Economy (London: Routledge, 2012) at 207. See also Tyler McCreary, New Relationships On The Northwest Frontier: Episodes In The Gitxsan And Witsuwit'en Encounter With Colonial Power (PhD Dissertation, York University, Geography Department, 2013) [unpublished].

64 Tsilhqot'in Nation v British Columbia, 2014 SCC 44 (CanLII), [2014] SCJ No 44 (QL) at paras 82-84. See also: Arthur Manuel, "Tsilhqot' in Case and Indigenous Self-Determination" (January-July 2014) 12 First Nations Strategic Bulletin.

65 See also Keewatin decision: Grassy Narrows First Nation v Ontario (Natural Resources), 2014 SCC 48 (CanLII). 
Kahnesetake, at Ipperwash, with the Lubicon Cree, at Gustafsen lake, at Cape Croker with Chippewas of Nawash, the Nu-cha-nulth at Clayoquout Sound, the Anishinabek at Grassy Narrows, the Yinka Dene Alliance and Northern Gateway pipeline, and on. ${ }^{66}$ In addition to these stories of anti-enclosure and anti-corporate immigration, ${ }^{67}$ it will be important in the articulation of how Indigenous laws and legal traditions might inform Canadian immigration (or post-Canadian access to the commons) to note some positive stories as well. This type of story telling, in addition to more formal education efforts, ${ }^{68}$ is necessary in order to counteract those other ideas that are just lying around.

Of course, the situation is much more complicated than simply worst-case scenarios or direct action against corporate and state extraction of resource wealth. For example, there is the privatized ability of First Nations as employers in Ontario and other provinces (as with other employers) to use the Provincial Nominee Program to nominate, fast-track, and (as employers) sponsor immigrants to live and work in their communities and eventually acquire Canadian permanent resident status. Other examples that complicate the picture further include Chinese-First Nations relations in British Columbia and Coast, Straits, and Interior Salish territories. ${ }^{69}$ Historically, these relations included stories of 'sanctuary' being provided to migrant Chinese railroad workers by Coast Salish peoples from their persecution by white Canadian workers and bosses. ${ }^{70}$ Another story relates to Musqueam-Chinese elder

66 See generally, online: Defenders of the Land $<\mathrm{http}: / / \mathrm{www}$. defendersoftheland.org/>. More specifically, see Leanne Simpson, "Elsipogtog Protest: We're Only Seeing Half the Story" The Huffington Post (22 October 2013); Dayna Scott, "Pipelines and Protests: The Legal Regulation of Dissent" (forthcoming); Dayna Scott, "Situating Sarnia: 'Unimagined Communities' in the New National Energy Debate” (2013) 25 J Envtl L \& Prac 81; Aaron Mills, "Aki, Anishinaabek, kaye tahsh Crown" (2010) 9 Indigenous LJ 107; Val Napoleon, "Behind the Blockades" (2010) 9 Indigenous LJ 1; Shiri Pasternak, On Jurisdiction and Settler Colonialism: The Algonquins of Barriere Lake Against the Federal Land Claims Policy (Phd Thesis, University of Toronto Department of Geography, 2013) [Pasternak, On Jurisdiction]; John Borrows, Crown and Aboriginal Occupations of Land: A History \& Comparison (Toronto: Ipperwash Inquiry Research, 2005); Irina Ceric, "Clayoquot Sound" in Immanuel Ness, ed, International Encyclopedia of Revolution and Protest (Chichester, UK: Blackwell, 2009) at 785-786.

67 See e.g. Delgamuukw, supra note 2.

68 See e.g. Eddie Benton Banai, "Shingwauk's Teaching Lodge" online $<$ https://www.youtube.com/watch?v=007d5QWBN0k>; Christine Chinkin, Shelly Wright \& Hilary Charlesworth, "Feminist Approaches to International Law: Reflections from Another Century" in Doris Buss \& Ambreena Manji, eds, International Law: Modern Feminist Approaches (Portland: Hart Publishing, 2005) 32, detailing Wright's work as Northern Director of Akitsiraq Law School in Iqaluit, Nunavut, in charge of transnational Indigenous legal education in Inuit, Canadian, and international law, including required learning of Inuktitut language; Borrows, Canada's Indigenous Constitution, supra note 51 at 228-238. For an extended discussion in the global context, see Kerry Sloan, "A Global Survey of Indigenous Legal Education and Research" (2013) Paper prepared for the University of Victoria, Indigenous Law Research Unit, online: Indigenous Bar Association $<$ http://indigenousbar.ca/indigenouslaw/wpcontent/uploads/2012/12/kls_world_indigenous_legal_education_complete.pdf > especially at 44-65 (Canadian developments). See also Recommendations 27 and 28 in Truth and Reconciliation Commission of Canada "Calls to Action" online $<$ http://www.trc.ca/websites/trcinstitution/File/2015/Findings/Calls_to_Action_English2.pdf $>$ at 3.

69 See e.g. Jean Barman, "Beyond Chinatown: Chinese Men and Indigenous Women in Early British Columbia" (2013) 177 BC Studies 39; Henry Yu, Vancouver Dialogues: First Nations, Urban Aboriginal and Immigrant Communities (Vancouver: City of Vancouver, 2011); Sarah Ling, "Rooted in the Land: Revitalizing Stories of Chinese and Musqueam Relations" (Paper delivered at the Encounters in Canada Conference, Toronto, 15 May 2013) (notes on file with author).

70 Interview of Arthur Manuel and Bill Chu (Date) (notes on file with author); see also David Wong, Escape to Gold Mountain: A Graphic History of the Chinese in North America (Vancouver: Arsenal Pulp Press, 2012). More recently, see Walia, supra note 17 (MV Ocean Lady and Sun Sea, and other examples of solidarity actions by Indigenous activists 
Larry Grant and his ironic preservation of Humulkyuam language and knowledge through his mother's marriage to a Chinese man (leading to the loss of her status, due to marrying out, but also removal of the threat of forced attendance (and loss of language) at residential schools). ${ }^{71}$ In story, there is also the example in Sky Lee's Disappearing Moon Cafe, of Chinese migrant worker Gwei Chang and his encounter with and brief marriage to Kelora Chen (daughter of Chinese and Indigenous parents), who took him in (lost, hungry, and looking for the bones of deceased railroad workers to send home) and showed him how to be in 'citizenship with the land' by introducing him to the territory and walking it together. $^{72}$ These and other stories and examples will be necessary in the face of the precarity of status for individuals under both immigration law and the Indian Act for, respectively, so-called 'low skill' migrant workers ${ }^{73}$ and First Nations people. They are equally compelling where there is a lack of status afforded to entire Indigenous nations. ${ }^{74}$ A particularly complicated case emerges in the recent story of Heather Harnois, a woman of Ojibwa descent who the government considers "neither aboriginal, nor Canadian" due to the effects of the 'second-generation cut-off' rule under both the Indian (parenting out) and Citizenship (birth abroad) Acts. ${ }^{75}$

This last 'neither... nor' example speaks to the situation where people are excluded from both sets of communities, despite having ties and relations to either, or both, Indigenous peoples and the Canadian state/society. Although described as 'unique', this situation is actually commonplace for all of the migrant workers in Canada who either enter without permanent resident status or lack any real opportunity to secure such status after entry (similarly so for those without immigration status). Despite individual and association employer rhetoric to the contrary, migrant workers are patently not 'one of the family' ${ }^{76}$ In fact, they are not one of the two families, whether Canadian or Indigenous ${ }^{77}$. As I argue below, such exclusion is troubling if our right to be here is, in fact, a treaty right to be here. ${ }^{78}$

and elders for criminalized and detained migrants and non-status people); Volpp, supra note 9.

71 See Barman, supra note 70; Yu, Vancouver Dialogues, supra note 70 at 39; and Ling, supra note 70. See also Mawani, Colonial Proximities, supra note 8; Henry Yu, "Tiger Woods Is Not the End of History: or, Why Sex across the Color Line Won't Save Us All” (Dec. 2003) 108:5 American Historical Review, online: History Cooperative $<$ http://www.historycooperative.org/journals/ahr/108.5/yu.html>.

72 Sky Lee, Disappearing Moon Café (Vancouver: Douglas \& McIntyre, 1990); See also Lee Maracle, "Yin Chin" in WH New, ed, Native Writers and Canadian Writing (Vancouver: University British Columbia Press, 1990)

73 See e.g. Bhatia, "In A Settled Country", supra note 13.

74 See e.g. Bonita Lawrence, Fractured Homeland: Federal Recognition and Algonquin Identity in Ontario (Vancouver: University of British Columbia Press, 2012); Bruce G Miller, Invisible Indigenes: The Politics of Nonrecognition (Lincoln: University of Nebraska Press, 2003). For non-recognitition in the face of negotiated agreements, see also Pasternak, On Jurisdiction, supra note 66.

75 "More Lost Canadians - Indian status and citizenship both out of reach for desperate Ontario mom", Vancouver Sun (25 July 2013) (likely to be forced to apply for Canadian permanent residence under humanitarian \& compassionate grounds).

76 Cf Macklin, supra note 44; Bakan \& Stasiulis, supra note 44.

77 See discussion in Johnson, supra note 3.

78 See James Sákéj Youngblood Henderson, "Sui Generis and Treaty Citizenship” (2002) 6:4 Citizenship Studies 415, at 417-433. 


\section{WE ARE ALL TREATY PEOPLE... BUT ONLY IF WE ARE ALL HERE TO STAY}

As noted above, the idea of a 'treaty right to be here"79 emerges from several sources, including Harold Johnson's book, Two Families ${ }^{80}$, but also, importantly, the work of Sa'ke'j Henderson (2002). ${ }^{81}$ Other prominent examples that 'We Are All Treaty People' range from the statement by Justice Linden in the Ipperwash Inquiry Report, ${ }^{82}$ and similar statements by Nihiyow (Treaty Six) international legal scholar Sharon Venne, ${ }^{83}$ and historian Jim R. Miller ${ }^{84}$, to, more recently, the Idle No More movement. Apart from these serious examples, there are also more satirical ones, such as the Briarpatch 'Settler Treaty Card ${ }^{\mathrm{TM}}$, 85 and the 'Certificate of Settler Status'. ${ }^{86}$

79 Cf PG McHugh, Aboriginal Title: The Modern Jurisprudence of Tribal Land Rights (Oxford: Oxford University Press, 2011). But see Kent McNeil, "Indigenous Rights Litigation, Legal History, and the Role of Experts" (2014) 77 Sask L Rev 173.

80 Johnson, supra note 3.

81 Sákéj Henderson, supra note 79 at 417-433 (citizenship presence relies and depends on treaties, in relation to Aboriginal legal orders and traditions, which did not have the concept of strangers so much as everyone was a guest; treaties remain the original constitution of Canada; and learning to belong to the territory or ecology). [cf Linebaugh, supra note 37].

82 Hon Sidney B Linden, Report of the Ipperwash Inquiry (Ottawa: Publications Ontario, 2007) vol 4 at 81 (Report into the shooting of Dudley George by OPP at peaceful occupation of provincial park which Ontario had failed to return to First Nation: "One of the lessons of Ipperwash is the realization that all of us in Ontario, Aboriginal and non-Aboriginal, are treaty people." See also "Settler Treaty Card", Briarpatch online: Briarpatch Magazine $<$ www.briarpatchmagazine.com>; JR Miller, Compact, Contract, Covenant: Aboriginal Treaty-Making in Canada (Toronto: University of Toronto Press, 2009). See also, Robinder Kaur Sehdev, "People of Colour in Treaty" in Ashok Mathur et al, eds, Cultivating Canada: Reconciliation through the Lens of Cultural Diversity (Ottawa: Aboriginal Healing Foundation, 2011) at 267-272; Saskatchewan Office of the Treaty Commissioner, "We Are All Treaty People" online $<$ http://www.otc.ca/education/we-are-all-treaty-people>; David Arnot, "Treaty Implemenation Report: Fulfilling the Covenant" and Federation of Saskatchewan Indian Nations, Response to Treaty Implementation Report (Office of the Treaty Commissioner, 2007) online $<$ http://www.otc.ca/education/we-are-all-treaty-people/treaty-implementationreport>.

83 See, eg, Sharon H Venne, "Treaties Made in Good Faith," in Paul W DePasquale, ed, Natives and Settlers, Now and Then: Historical Issues and Current Perspectives on Treaties and Land Claims in Canada (Edmonton: University of Alberta Press, 2007), 5; also, S. Pasternak, above supra note 66.

See also Sharon Helen Venne, Our Elders Understand Our Rights: Evolving International Law on Indigenous Peoples (Penticton, BC: Theytus Books, 1999).

84 Miller, supra note 82. In related vein, J.R. Saul notes that we are a 'Metis nation' (though without real discussion, or distinction, from the Metis Nation of Manitoba, etc. but more in the generic sense of 'mixed' Europeans and First Nations generally). See e.g. D’Arcy G Vermette, Beyond Doctrines of Dominance: Conceptualizing a Path to Legal Recognition and Affirmation of the Manitoba Metis Treaty (LLD Thesis, University of Ottawa, Common Law Section, Faculty of Law, 2012) [unpublished].

85 See "Settler Treaty Card", supra note 83 and Tyler McCreary, "Settler Treaty Rights", Briarpatch magazine (August 2005) online: Briarpatch Magazine <www.briarpatchmagazine.com/articles/view/settler-treaty-rights>.

86 'Certificate of Settler Status' (designed by Dawnis Kennedy) in Nadia 'Ziishiib' Verrelli, Minnawaanigogiizhigok/Dawnis Kennedy and Amar Bhatia, "The Politics of Inclusion/Exclusion: Best Practices in Immigration Policy Since 1492" (Paper delivered at 'Encounters in Canada: Contrasting Indigenous and Immigrant Perspectives' Conference, Toronto, 15 May 2013). 

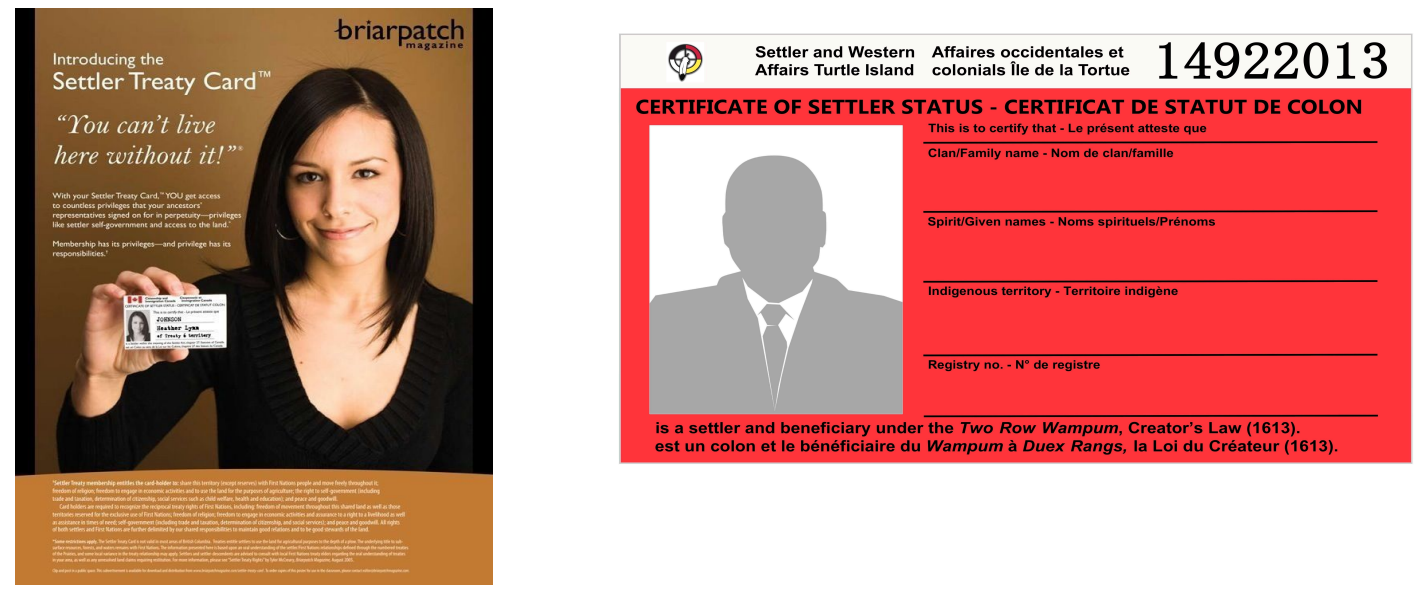

Underlying all of these articulations, even the satirical, is the recognition that a relationship exists, that it underpins continued presence on the land, and that it cannot be extinguished. The quality of the relationship can be summarized in this way: "We desire the fullest, richest, and most interesting and mutually beneficial relationship possible in the least obtrusive and most congenial way possible, to engage the being/phenomenon - its history, its condition, and its conduct in relation to ourselves. [...] We imagine that this desire for relationship might be driven by our mutual right to be." $\$ 77$

In his book, Two Families, written in response to a law student's request, Nihiyow (Cree) lawyer Harold Johnson takes an uncommon starting point when looking at the diversity of peoples in Canada and their respective rights to be here. ${ }^{88}$ Writing from a northern Cree perspective and a small territory in the centre of Saskatchewan (the 1889 adhesion to Treaty No. 6), Johnson initially notes where he is from and that he does not and cannot "speak for all Aboriginal peoples." 89 He also follows the relational approach of Cree law: "Kiciwamanawak, my cousin: that is what my Elders said to call you. When your family came here and asked to live with us on this territory, we agreed. We adopted you in a ceremony that your family and mine call treaty. [...] At Treaty No. 6 the Cree adopted the Queen and her children. We became relatives." Johnson relates this legal history of the ceremony of treaty, which were "adoptions of one nation by another" under Cree law, ${ }^{91}$ in order to explain the consistencies and potential coexistence of Cree and Canadian supreme laws. This 'familiarization' of the treaty process is geared towards a shift away from privileging pieces of paper (e.g. the Constitution; federalprovincial resource transfer agreements $)^{92}$ in order to perceive the actual and ideal relationships between

87 Lee Maracle, "Oratory on Oratory", in S Kamboureli \& M Roy, eds, Trans.Can.Lit: Resituating the Study of Canadian Literature (Waterloo: Wilfrid Laurier University Press, 2007), 55 at 68 (emphasis added).

88 Johnson, supra note 3 at 13.

89 Ibid at 11

90 Ibid at 13. As noted in the prefatory endorsement letter from elected Chief Lionel Bird (Montreal Lake Cree Nation), Johnson's use of "the inclusive 'Kiciwamanawak' in the discussion formally introduces him as the speaker for all of us to all of you. If he were to use Niciwamak, he would be speaking only for himself to all of you." While endorsed by the Montreal Lake Cree, this endorsement of course does not extend to or speak for all Aboriginal people.

91 Ibid.

92 See ibid at 90 ("my family did not adopt a piece of paper") and at 92 (non-abrogation of treaties by Constitution, since treaties are the source of Canadian justification to be here and have a constitution in the first place). 
two groups of people, to "suggest how we might live together as two families sharing the same territory. I will never suggest that you go back where you came from, for I assure you, Kiciwamanawak, that you have a treaty right to be here." ${ }^{.93}$ Johnson goes into further detail on this point of familial, national adoption later in the book:

When your ancestors came to this territory, Kiciwamanawak, our law applied. When your ancestors asked to share this territory, it was in accordance with our law that my ancestors entered into an agreement with them. It was by the law of the Creator that they had the authority to enter treaty. The Creator gave us several ceremonies through which we experience, learn, and practice the law of the Creator. One of these ceremonies is for adoption. While your law is divided into several areas - tort, property, criminal, contract, taxation - our law is primarily concerned with the maintenance of harmonious relations. [...] It was in accordance with the law of adoption that my family took your ancestors as relatives. We solemnized the adoption with a sacred pipe. The promises that my ancestors made are forever, because they were made under the Creator's law. This adoption ceremony is what we refer to when we talk about the treaty. ${ }^{94}$

Unlike dominant approaches in liberal theory, Johnson begins with the application of Cree law, the Crown's request to share the territory, and the irrevocable adoption through treaty of the ancestors of those who are now the inheritors of Canadian settler state sovereignty.

Rather than starting by assessing the legitimacy of special self-government rights for national minorities ${ }^{95}$, Johnson looks at the legitimacy of the state that purports to grant these rights in the first place. In reviewing section 52 of the Constitution Act, 1982, ${ }^{96}$ Johnson responds with the following:

Kiciwamanawak, your Constitution is only how your family will run itself. It is not the supreme law of this territory. Your Constitution is subservient to and dependent of the treaties for its legitimacy. There is no other legitimate basis for your occupation and use of this territory. It is only by treaty that you have any rights here at all. [...] If there is any supreme law, it must be the law of adoption. If your family and mine are going to live in this territory together, with truth and honesty, we have to live as relatives. Sorry, Kiciwamanawak, you're stuck with me. ${ }^{97}$

In this passage, Johnson puts forward a radical vision and the fundamental link drawn between the mutual adoption of treaty - the health of that permanent relationship between the two families - and the ongoing legitimacy of the Canadian state and the rights of its citizens to be here. ${ }^{98}$ Perhaps obviously, but still important to note, Johnson does not approach Cree law and treaties from their absence or their erasure.

$93 \quad$ Ibid at 14 (emphasis added).

94 Ibid at 27.

95 Contrast with e.g. Kymlicka, supra note 11.

96 "The Constitution of Canada is the supreme law of Canada, and any law that is inconsistent with the provisions of the Constitution is, to the extent of the inconsistency, of no force or effect." Constitution Act, 1982, being schedule B to the Canada Act 1982 (UK), 1982

97 Johnson, supra note 3 at 105 (emphasis added). Johnson makes the same point throughout the book. For example, in discussing s. 25(b), Johnson notes that "This section of the Constitution is written backwards: it is your family that derives rights from treaty" at 100 .

98 Whether this vision is one of radical legal pluralism, or instead radical incommensurability, remains to be seen. See Eve Tuck \& K Wayne Yang, "Decolonization is not a metaphor" (2012) 1:1 Decolonization: Indigeneity, Education \& Society 1 at 13-17. 
While an important improvement in terms of shifting away from an approach that might only reify the state to the exclusion of other sources of power and authority, how does the relational acknowledgment of our treaty right to be here (to have any rights at all) address the concerns raised by racialized settlers and migrants from the global South? As noted by Amadahy \& Lawrence in the context of the (now 400-year-old) Gus-Wen-Tah or Two Row Wampum, which set the frame for many treaty relations that followed:

Further questions emerge regarding the framework of the Two Row Wampum, often referred to as the agreement that sets out how settlers and Indigenous people are supposed to coexist on Turtle Island. The wampum belt depicts two parallel rows of lavender beads running the belt's length. Elders tell us this symbolizes that White settlers and Indigenous people agreed to sail in their canoes or boats down the waterway respecting and not interfering with each others' progress nor interfering with each others' communities (another "treaty" not kept). The notion that Indigenous nations can coexist with the Canadian state, whose ideology, values, and institutions lead to the poisoning of the air, water, and land that we all depend on; that forms the basis of our identities and cultures, is increasingly coming into question. ${ }^{99}$

Although it is largely tangential to his greater argument and he spends only a small portion of the book on the issue, Johnson does write about two places that could address racialized settlers and migrants of colour.

First, in his reading of section 27 of the Constitution Act, 1982, which reads as follows: "Multicultural heritage: This Charter shall be interpreted in a manner consistent with the preservation and enhancement of the multicultural heritage of Canadians." 100 However, Johnson immediately emphasizes: "My family are not the same as other minority groups within your family. We are happy that many people from different parts of the world have come to live here. They are as welcome as you are." 101 This distinction is interesting because noting that immigrants "are as welcome as you are" implies two things: 1) settlers are newcomers, too, despite their attribution of 'newness' to immigrants only; 2) immigrants are no less (or more) welcome than those who have come before. Johnson goes on to modify this relative stance of welcome through the reality of treaty, which is worth quoting at length here:

My family adopted your family at treaty. We did not adopt or make treaty with those who are now minorities within your family. To my family, the minorities are all members of your family. They are your responsibility. You adopted them through your ceremony of immigration and naturalization. To the extent that they are your relatives through adoption, they are also our relatives, because you and $I$ are related.

Your family has developed a huge body of law in relation to minorities. You have sought to find peace among yourselves. If my family accepts designation as a minority group, then we would put ourselves under that body of law. I am not in any way criticizing your treatment of minorities, Kiciwamanawak. I am simply stating that my family has a different relationship with you. We have a treaty relationship. Our

99 See Lawrence \& Amadahy, supra note 6 at 131; cf Sehdev, supra note 83 at 273 (need to "focus attention on decolonizing treaty" from historical artifacts to processes of "making and keeping good relations") but see also Tuck and Yang, ibid and references on One Dish treaty, supra note 5.

100 Constitution Act, 1982, supra note 97.

101 Johnson, supra note 3 at 100 (emphasis added). 
differences must be worked out in accordance with the treaties and not through your law in relation to minorities. ${ }^{102}$

For Johnson, immigrants (among others) are members, and the responsibility, of Canada first, adopted through the ceremonies of immigration and naturalization. Membership in the Canadian family in turn leads to a relationship with Johnson's family due to the two families' treaties. However, this membership of minorities could be something less than the position of those who are descendants of the original treaty partners. He further segments the hierarchy of laws: treaty relationship between two families versus the one family's body of law in relation to minorities. While Johnson's desire to draw distinctions from minorities and the many people from different parts of the world who have come to live in Canada is understandable given the history of assimilation that characterizes government and non-government approaches to both groups, ${ }^{103}$ it does not necessarily address the concerns of those who have not yet been adopted by Canada.

More specifically, Johnson appears to characterize minorities - for whom Canada is responsible - as those who are already full members through immigration and naturalization. Behind this characterization, there is an assumption that such minorities have had a consensual process of adoption into the Canadian family that is analogous to the treaty relationship described between Johnson's family and the Canadian family. The issues of full membership and consensual relationships, versus precarious, temporary, and non-status people in coerced and forced migration, cannot be so easily assumed. This assumption by Johnson is similar to the footnoting of 'pre-existing communities with attachments to the land' in Bosniak and (as shown by Volpp) that is characteristic of immigration law and scholarship more generally. The incomplete picture in Aboriginal law and treaty rights (directed at the Canadian state and its citizens as treaty partners and people carrying rights and responsibilities) is mirrored in the silos of immigration law (directed at the Canadian state as the sole authority on the right to be here and stay here). As noted above, Lawrence \& Dua and Sharma \& Wright's work seeks to move beyond these divides in the best of the critical anti-racist and Indigenous scholarship outside of law. However, this literature also demonstrated a further gap with respect to the place and authority of Indigenous laws and legal traditions in a context faced with these simultaneous (not necessarily competing) demands. I do not want to over-determine Johnson's brief discussion of immigrants in the context of his larger and powerful argument about treaties and treaty relations. However, it is also worth noting that he is keenly aware of the difference that citizenship determination makes, even if it is not reflected in his uncritical ${ }^{104}$ approach to Canadian citizenship and immigration law.

For example, Johnson critiques the underlying assumption of subsection 35(2) of the Constitution, which "purports to determine the Aboriginal peoples of Canada as the Indian, Inuit, and Metis peoples. Kiciwamanawak, you haven't the right to tell anyone who they are. It is not for you to decided who is

102 Ibid at 100-101 (emphasis added).

103 For just one excellent example, see Bohaker \& Iacovetta, supra note 7 at 427-461. See also Statement of the Government of Canada on Indian Policy (White Paper) 1969 online $<$ http://www.aadncaandc.gc.ca/eng/1100100010189/1100100010191>; Indian Chiefs of Alberta, Citizens Plus ('Red Paper') (Edmonton: Indian Association of Alberta, 1970); Harold Cardinal, The Unjust Society: the Tragedy of Canada's Indians (Edmonton: M.G. Hurtig, 1969); Sally Weaver, Making Indian Policy: The Hidden Agenda 1968-70 (Toronto: University of Toronto Press, 1981).

104 ("I am in no way criticizing your treatment of minorities") in Johnson, supra note 3 at 100. 
or is not an Indian, who is or is not a member of my family." 105 This core feature of self-determination relates to the governmental myth of the "vanishing Indian"106 as much as it does to the reality of the government-perpetuated shrinking of the population of those eligible for entitlement to registration as Indians under the Indian Act. Although this subject has filled entire books, Johnson puts the point succinctly that: "Elders within my family are afraid that if your determinations are allowed to continue, within a very few generations there will no longer be anyone who meets your requirements to belong to my family. If we allow you to continue to say who is or who is not in our family, our family will disappear." ${ }^{107}$ Clearly, the concern for Johnson is self-determination and how the lack of consent in the eligibility rules of the Indian Act, especially those forestalling the transmission of status between women and their children from non-status men, forestall the ability of communities and peoples to sustain themselves. ${ }^{108}$

Although not his main focus by any stretch, there is clearly a relationship between immigrants and Indigenous peoples in Johnson's view. This relationship emerges through formal adoption into the Canadian family, which in turn leads to relative status with Johnson's family through the laws of adoption, or treaties, between these two founding families. So, as noted in the quotations at the start of this article, we're stuck with one another and supposedly all here to stay. But neither Johnson's account nor the Supreme Court of Canada's approach to reconciliation speak to those situations where migrants and immigrants have a relationship with the Canadian family, but remain without full recognition or status. This precarious status emerges because people are: 1) formally incorporated for temporary periods without the possibility of permanent status (e.g. the 'permanently temporary' so-called 'low skill' temporary foreign workers subject to the 4-in-4 rule); 2) formally incorporated for seasonallyrestricted work with indefinite returns foreclosing permanent residence (e.g. the 'permanently recruited' of the Seasonal Agricultural Worker Program); or 3) because they are permanent members of the community who lack the avenues for formal incorporation or adoption (e.g. people living without immigration status due to expired visitor visas, failed asylum claims, etc.). ${ }^{109}$

Put more bluntly, if so-called 'low skill' (often deskilled) racialized migrant workers are 'not one of the family', and in most cases can never get landed or citizenship status, then clearly 'we' are not all treaty people. Further, I would argue that Canada's treaty right to be here cannot plausibly include the right to import people as commodities who never have the right to stay here, can never become treaty people, and are never subject to treaty obligations to share and care for the land, life and waters. As noted in some of the quotations at the outset of this article, this policy is especially suspect when developed at the bidding of hard-to-hold accountable industries (and recruiters) manning themselves with involuntarily temporary, non-treaty people in order to exploit the resources of the land for shortterm gains and private profit. Similarly, while Canada and Canadians have a treaty right to be here, this

105 Johnson, supra note 3 at 103.

106 See e.g. Bohaker \& Iacovetta, supra note 7 at 434.

107 Johnson, supra note 3 at 104 (emphasis added). See also references above, supra note 55.

108 Johnson, ibid at 104. See also, for example, Larry Gilbert, Entitlement to Indian status and membership codes in Canada (Scarborough, ON: Carswell, 1996); Shin Imai \& Kate Buttery, "Indigenous Belonging: A Commentary on Membership and Identity in the United Nations Declaration on the Rights of Indigenous People" (2013) Osgoode Digital Commons Working Paper online: $<$ http://digitalcommons.osgoode.yorku.ca/all_papers/49>.

109 For a book length treatment of this spectrum of precarity, see Luin Goldring \& Patricia Landolt, eds, Producing and Negotiating Non-Citizenship: Precarious Legal Status in Canada (Toronto: University of Toronto Press, 2013). 
cannot be construed as a treaty right to undermine the treaties, whether directly, by preventing the maintenance and growth of Indigenous nations (e.g. marrying out or second-generation cut-off rules) or indirectly, by hoarding permanent status from low-skilled migrant workers and others. So, if we are all treaty people, and have a treaty right to be here, then these words, and the rights and responsibilities envisioned in living treaty relations, only have meaning if we are truly all here to stay (contrary to Lamer C.J.'s assumption). At the least, I believe that such an understanding requires recognizing both inherent and shared authority by Indigenous peoples and nations over immigration to unceded and shared territories. As noted above, I am not simply talking about another layer of actual or pseudoconsultation on the 'levels and mix' in the immigration targets developed annually by Citizenship and Immigration Canada. Fundamentally, it could be shared authority arising from treaty relations, respectful of treaty rights and responsibilities, in shared and traditional territories, and inherent rights in unceded territories, all informed by Indigenous laws and legal traditions not constrained solely by the choices presented by settler colonialism and neoliberal economic globalization. As noted with respect to the potential of commoning discussed above, my argument undoubtedly raises more questions than answers. ${ }^{110}$ At least, however, it attempts to avoid the disciplinary segregation described above and counts Indigenous political and legal traditions among the key sources of authority in these questions and answers.

\section{INDIGENOUS LEGAL TRADITIONS AND CITIZENSHIP WITH THE LAND}

On this point, I have to note that there is no way to do justice here to the vast array of Indigenous laws and legal traditions that exist (notwithstanding ongoing structures of settler-colonialism ${ }^{111}$ ), both for lack of knowledge and for lack of space. For the sake of brevity, logic, and also reality, I will work from the assumption (asserted by Borrows, and Napoleon \& Friedland) that Indigenous laws and legal traditions do, in fact, exist and have done so for a long time, defined by their diversity, continuity, repression, survival, and adaptability. ${ }^{112}$ Recent work on Indigenous legal traditions is especially striking given the relatively recent rarity of published scholarship on state-based Aboriginal law (let alone Indigenous laws) in the late sixties and early seventies. ${ }^{113}$ More specifically, this new research and writing has been explicit in recognizing and naming specific Indigenous legal traditions and

110 Tuck and Yang, supra note 99 at 13-17.

111 See Patrick Wolfe, "Settler colonialism and the elimination of the native" (Dec. 2006) 8(4) Journal of Genocide Research 387-409 at 388. See also: Patrick Wolfe, Settler Colonialism and the Transformation of Anthropology (London: Cassell, 1999) at 2.

112 See e.g. Hadley Friedland, Accessing Justice and Reconciliation - IBA Accessing Justice and Reconciliation Project: Final Report (February 4, 2014) online: Indigneous Bar Association $<$ http://indigenousbar.ca/indigenouslaw/wpcontent/uploads/2013/04/iba_ajr_final_report.pdf>; John Borrows, "Tracking Trajectories: Aboriginal Governance as an Aboriginal Right" (2005) 38 UBC L Rev at 293-296. The first Indigenous law degree has been proposed at the University of Victoria's Faculty of Law (see Borrows, Canada's Indigenous Constitution, supra note 51 at 228-238), in part based on the previous Akitsiraq law program including Inuit law (see Sloan, supra note 68 at 44-65 and Chinkin et al, supra note 68).

113 See Michael Jackson, Q.C., "A Model of Scholarship” (2005) 38 U.B.C.L.Rev. 315 at 316. See also Kenneth Lysyk, "The Unique Constitutional Position of the Canadian Indian" (1967) 45 Can. Bar Rev. 513; Native Rights in Canada (Toronto: Indian-Eskimo Association of Canada, 1970); Peter A. Cumming \& Neil H. Mickenberg, eds., Native Rights in Canada, $2^{\text {nd }}$ ed. (Toronto: Indian-Eskimo Association of Canada, 1972). 
communities as and where available and appropriate (e.g. Mohawk nation of the Haudenosaunee Confederacy). In part, this naming is a function of the wide diversity of Indigenous legal traditions that span these lands and waters known variously as Great Turtle Island or Canada, etc. ${ }^{114}$

The point of diversity cannot be emphasized enough here; Indigenous legal traditions are neither monolithic nor homogeneous. For two of the leading proponents of this revitalization, John Borrows and Val Napoleon, it is especially important to underscore this point, as well as the need to avoid romanticizing (and thus both misrepresenting and freezing) Indigenous laws and legal traditions. ${ }^{115}$

With at least these two caveats in mind (diversity not homogeneity; reality not romanticism), Borrows sets out some of this diversity:

The earliest practitioners of law in North America were its Indigenous inhabitants. [...] They include, among others, the ancient and contemporary nations of the Innu, Mi'kmaq, Maliseet, Cree, Anishinabek, Hodinohso:ni, Dakota, Lakota, Nakota, Assinaboine, Saulteaux, Blackfoot, Secwepemec, Nlha7kapmx, Salish, Nuu-Chah-Nulth, Kwakwaka'wakw, Haida, Carrier, Tsimshian, Nisga'a, Gitksan, Tahltan, Tlingit, Gwichin, Dene, Inuit, and Métis. In relation to this diversity, I wrote in Recovering Canada: The Resurgence of Indigenous Law [citation omitted]:

The traditions of these Indigenous peoples can be as historically different from one another as other nations and cultures in the world. For example, Canadian Indigenous peoples speak over 50 different Aboriginal languages from 12 distinct language families that have as wide a variation as those of Europe and Asia. The linguistic, genealogical, political and legal descent of these nations can be traced back through millennia to different regions or territories in northern North America. This explains the wide variety of laws found in Indigenous groups. ${ }^{116}$

Similarly, in the Accessing Justice and Reconciliation [AJR] project with the Indigenous Bar Association (IBA) and others, Val Napoleon (Saulteau; Gitanyow (Gitksan), House of Luuxhon, Ganada (Frog) clan)), Hadley Friedland, and a team of researchers examine how various Indigenous legal traditions and partner communities address harm and conflict within and between groups, including: Coast Salish law (e.g. Snuneymuxw First Nation; Tsleil-Waututh Nation), Tsilhqot'in law (Tsilhqot'in National Government), Northern Secwepemc law (T'exelc Williams Lake Indian Band), Cree law (Aseniwuche Winewak Nation), Anishinabek law (Chippewas of Nawash Unceded First Nation \#27), and Mi'kmaq law (Mi'kmaq Legal Services Network, Eskasoni). ${ }^{117}$ These different Indigenous legal traditions stem from a diversity of Indigenous nations and a spectrum of sources, including (following

114 See also Napoleon \& Friedland, "Indigenous Legal Traditions: Roots to Renaissance" in Markus D. Dubber and Tatjana Hörnle, eds., The Oxford Handbook of Criminal Law (Oxford: Oxford University Press, 2014) at 227 ("Across Canada alone, there are eleven major linguistic groups and within these, there are sixty distinct Indigenous peoples with numerous regional dialects.") and note 3 ("There are 500 distinct Indigenous societies in North America.").

115 See e.g. Borrows, Canada's Indigenous Constitution, supra note 51 at 10-11.

116 For examples relating to Mi'kmaq, Haudenosaunee, Anishinabek, Cree, Metis, Carrier, Nisga'a, and Inuit legal traditions, see Borrows, Canada's Indigenous Constitution, supra note 51 at 301, note 6 and at 59-104.

117 See Friedland, supra note 112 at 5. Even this diversity does not speak to the actual multiplicity at work within these laws and legal traditions depending on the local community and variations in storytellers, such as different versions of the story of Mandamin (see Borrows, Canada's Indigenous Constitution, supra note 51 at 274, 281). 
one working typology by Borrows): natural law, sacred law, deliberative law, positivistic law (e.g. band membership codes; National constitutions), customary law, and treaties. ${ }^{118}$

As just one example ${ }^{119}$ that might inform membership decisions or help constitute or re-constitute Indigenous immigration laws, I draw on an article (and book chapter) by John Borrows. Borrows proposes the notion of 'Aboriginal control of Canadian affairs' that are important to them, in contrast to the historical push for 'Indian control of Indian affairs'. ${ }^{120}$ He develops this notion in line with the prospect and reality of 'landed' citizenship, or being in citizenship with the land, at Neyaashiinigmiing (Cape Croker) on the western shores of Georgian Bay:

Our births, lives, and deaths on this site have brought us into citizenship with the land. We participate in its renewal, have responsibility for its continuation, and grieve for its losses. As citizens with this land, we also feel the presence of our ancestors, and strive with them to have the relationships of our polity respected. Our loyalties, allegiance, and affection is related to the land. The water, wind, sun, and stars are part of this federation. The fish, birds, plants, and animals also share this union. Our teachings and stories form the constitution of this relationship, and direct and nourish the obligations this citizenship requires. The Chippewas of the Nawash have struggled to sustain this citizenship in the face of the diversity and pluralism that has become part of the land. This has not been an easy task. Our codes have been disinterred, disregarded, and repressed. What is required to reinscribe these laws, and once again invoke a citizenship with the land? ${ }^{121}$

Given this emphasis on relations with the land, life and water, which in turn reflects the teaching of 'All My Relations', it is understandable that Borrows does not favour limits on Aboriginality based on blood or genealogy. ${ }^{122}$ Instead, he leaves room for others, noting that it could be "appropriate to have rigorous citizenship requirements based on other grounds (much more than kin-based groups)" due to the "social, political, legal, economic, and spiritual ideologies and institutions that are transmitted through cultural systems not exclusively dependent on ethnicity". ${ }^{123}$ He notes that these ideologies and institutions can

118 See numerous examples at Borrows, Canada's Indigenous Constitution, supra note 51 at 23-58.

119 I discuss this issue at greater length in my dissertation.

120 John Borrows, “Landed Citizenship: Narratives of Aboriginal Political Participation” in Alan C. Cairns et al., Citizenship, Diversity \& Pluralism: Canadian and Comparative Perspectives (Montreal \& Kingston: McGill \& Queen's University Press, 1999) at 326-347 (Borrows 1999) (reprinted as "Landed Citizenship: A Declaration of Interdependence" in John Borrows, Recovering Canada: The Resurgence of Indigenous Law (Toronto: University of Toronto Press, 2002). Borrows broadly categorizes the message of Harold Cardinal in The Unjust Society (1969), and in the activism of Cardinal and others at the time, under the theme of 'Indian control of Indian affairs' (such as with education).

121 Ibid., emphasis added. See also: Lee Maracle, I Am Woman: A Native Perspective on Sociology and Feminism (Vancouver: Press Gang Publishers, 1999) at 36-42 (regarding spiritual and traditional qualities as political and legal ones that prescribe, in part, caretaking of the land).

122 Borrows 1999, supra note 120 at 339. See also J. Borrows, "Seven Generations, Seven Teachings: Ending the Indian Act" (commissioned Research Paper for the National Centre for First Nations Governance, May 2008) online $<\mathrm{http}$ ///fngovernance.org/resources_docs/7_Generations_7_Teachings.pdf $>$; Bonita Lawrence, "Real” Indians and Others: Mixed-Blood Urban Native- Peoples and Indigenous Nationhood (Lincoln, NB \& London: University of Nebraska Press, 2004). More recently, and on the complex multiplicity of relations, see Robert A Innes, Elder Brother and the Law of the People (Winnipeg: University of Manitoba Press, 2013) and Michael Asch, On Being Here to Stay: Treaties and Aboriginal Rights in Canada (Toronto: University of Toronto Press, 2014) at 138.

123 Borrows 1999, supra note 120 at 340. 
be learned and adopted by others 'with some effort', which could ultimately lead to consideration of "implementing laws consistent with these traditions to extend citizenship in Aboriginal communities to non-Aboriginal people". 124

In fact, for Borrows, this extension of citizenship, flowing from Aboriginal control of Canadian affairs that are important to and impact on Aboriginal people, is inherently tied to continuing Anishinaabe citizenship with the land. He notes that Indigenous peoples still participate in their traditional territories, notwithstanding the borders and boundaries of reserves, relying on them for food, water, medicine, memories, friends, and work. ${ }^{125}$ Aboriginal control of Canadian affairs thus "... provides a discourse which simultaneously recognizes the meaningful participation of Aboriginal people with one another, and with their non-Aboriginal neighbours. It contains a deeper commitment to preserve and extend the special relationship Aboriginal peoples have with the land."126 This deep commitment to preserve and extend the special relationship with the land - the openness of landed citizenship informed by the teaching of 'All My Relations' - speaks to a new law of immigration or adoption. Of course, it is not new under Anishinaabe law, but it would be new under treaty codetermination, shared authority in shared territories (traditional or otherwise) with Canada, and inherent rights in unceded lands over immigration to Turtle Island. Furthermore, the admission to membership of individuals and families posited by Borrows echoes the larger scale adoption of groups, communities, and nations via treaty relationship under Nihiyow law articulated by Johnson, as well as the Haudenosaunee Kaianerekowa in the "Laws of Adoption". 127

The existence of living legal traditions of Indigenous nations, in conjunction with treaties/laws of adoption as the supreme laws of the land, underpin my argument for the necessity of questioning the Canadian state's monopoly over access, status, and belonging in the contexts of Canadian immigration and Indigenous self-determination. Living in relationship with one another on shared territories makes this a matter of common sense, as does recognizing that unjustly temporary or precarious immigration status only undermines treaties and treaty relations. And, although it remains to be seen, Indigenous immigration laws need not replicate the exclusions of Canadian immigration laws or the Indian Act or Indian Act-like band membership codes ${ }^{128}$. These different sources and examples of Indigenous laws of making and keeping relations can serve as means for Indigenous societies to "keep their legal traditions alive and connected to broader normative bases" through living communities. ${ }^{129}$ These are positive reasons to begin to work towards answering these questions. As I have noted above, negative reasons exist as well, such as the fact that the Canadian state continually seeks the restriction of status Indigenous populations in concert with private sector exploitation of Indigenous reserve, treaty,

124 Ibid., emphasis added.

125 Ibid at 342; see also Rauna Kuokkanen, Reshaping the University: Responsibility, Indigenous Epistemes, and the Logic of the Gift (Vancouver: University of British Columbia Press, 2007).

126 Borrows 1999, supra note 120 at 342.

127 John Fadden, The Great Law of Peace of the Longhouse People: Iroquois, League of Six Nations = Kaianerekowa hotinonsionne (Mohawk Nation via Rooseveltown, N.Y.: Akwesasne Notes, 1977) 66-70. Cf. Taiaiake Alfred, Peace, Power, Righteousness: An Indigenous Manifesto (Don Mills, ON: Oxford University Press,1999) at 126 (cautioning against reifying this law in a version reduced to text).

128 See also Borrows, Canada's Indigenous Constitution, supra note 51 at 157-164 (territorial application of Indigenous legal traditions to non-members informed by their wider democratic basis).

129 Ibid at 56. 
unceded, and traditional territories. This resource exploitation is supported by the expansion of 'low skill' temporary migrant worker programs that commoditize workers and, almost universally, preclude their emergence as permanent residents, citizens, or treaty people, let alone acquiring landed citizenship requiring relationship with, and care-taking of, the land, life and waters. Finally, this approach does not preclude more radical solutions, such as commoning, which seek to move past treaty relations with states entirely. It is emphatic, however, that any such solutions must be informed by the laws and legal traditions of Indigenous peoples and nations, including, for example, understandings of ecological citizenship, taking care of the Common Dish or the Bowl with One Spoon, and other host laws. ${ }^{130}$

After all, the completion of the Indian Act's mission, in concert with modern treaties predicated on extinguishment of Aboriginal title (never mind Indigenous ownership and jurisdiction), only cements the monological sovereignty of the Crown with respect to its acts of settlement, citizenship and immigration. Ultimately, Harold Johnson is concerned for the disappearance of his family. At the least, Amadahy \& Lawrence are concerned for the lack of standing of black people in both Canada and Indigenous nations, as are Sharma \& Wright with respect to racialized immigrants and migrants of colour. Whether on the path to a full-blown commons ${ }^{131}$, or something else entirely ${ }^{132}$, it seems imperative to recognize along the way that we, as well as the Crown and state, only have a treaty right to be here (where we have one at all). ${ }^{133}$ But only if the treaties exist and are honoured in their full spirit and intent, informed by Indigenous laws and legal traditions. Doing so requires that 'we' must all be treaty people who are here to stay, in relation to one another, with territories, burdens, bowls, dishes, and spoons shared between all our relations.

130 See various references, supra note 5. See also Leanne Simpson, "Looking after Gdoo-naaganinaa: Precolonial Nishnaabeg Diplomatic and Treaty Relationships" (2008) 23 Wicazo Sa Rev. at 37-42 (only taking as much as needed, sharing everything, and not wasting any part of the animal in accordance with Nishnaabeg environmental ethics, which required decision making cognizant of impact upon "the plant and animal nations, in addition to the next seven generations of Nishnaabeg," in turn providing "an ancient template for realizing separate jurisdictions within a shared territory"). See also Bhatia, "In A Settled Country”, supra note 13 at 1296 (citing Maracle on host law: everybody eats). More generally, see Ruth Koleszar-Green, "What is a 'Guest'?” at 'Sovereignties \& Colonialisms: Resisting Racism, Extraction and Dispossession’ 2015 Critical Ethnic Studies Association Conference in Toronto on April 30, 2015 (conference presentation, notes on file with author).

131 But see Neeson, supra note 36; and Greer, Maddison, and Caffentzis, supra note 49 (all for historicizing and not romanticizing the commons, whether colonial, Indigenous, or otherwise).

132 See e.g. Robert Latham's concluding chapter in Leah F Vosko, Valerie Preston \& Robert Latham, eds, Liberating Temporariness?: Migration, Work, and Citizenship in an Age of Insecurity (Kingston: McGill Queens University Press, 2014) at 339-364.

133 See relevant references supra notes 78-84. Se also Asch, supra note 122. Building on his decades of earlier work, as well as the writing of Harold Johnson, Robert A. Williams, John Borrows, and Leanne Simpson, Asch puts forward the fundamental 'linking principle' that the treaty relationship alone is sufficient to ensure we are here to stay as equal members of two families (e.g. at 118-119, 152). However, and in the context of this excellent book, Asch does also briefly note that "On this matter there are no 'new immigrants,' for we are all here to stay" (164), which tends towards the same assumptions of permanence and consent that I think require unpacking in the context of transnational migration and migrant work. I discuss the promises and premises of treaties and migration in greater detail in a separate chapter of my dissertation. 